\title{
Natural Aging Behaviour of the EN AW 6082 and Lead Free EN AW 6023 Aluminium Alloys
}

Martin Fujda, Miloš Matvija, Miroslav Glogovský, Ivan Orišenko

Faculty of Materials, Metallurgy and Recycling, Technical University of Kosice. Letna 9, 04200 Kosice. Slovakia. Email: martin.fujda@tuke.sk,milos.matvija@tuke.sk,miroslav.glogovsky@tuke.sk, ivan.orisenko@student.tuke.sk

The natural aging behaviour of EN AW 6082 aluminium alloy and lead-free EN AW 6023 aluminium alloy with good free cutting machinability was investigated using Vickers microhardness measurements, tensile test analysis, and a light microscopy characterisation. The different chemical composition of the analysed alloys did not affect the alloys microhardness after quenching, but the solid solution grain sizes of the quenched alloys differed greatly. The microhardness and tensile strength of EN AW 6082 increased with aging time right after alloy quenching. On the contrary, microhardness and tensile strength of lead-free EN AW 6023 increased markedly until after 500 hours of natural aging. The natural aging of the 6023 alloy could be suppressed by the formation of Sn-vacancy pairs after alloy quenching that impede the strengthening clusters formation. Finer grains of solid solution that were found in the 6023 alloy microstructure resulted in higher tensile strength and lower ductility of the 6023 alloy compared to the 6082 alloy, even though the microhardness of the naturally aged 6023 alloy state was lower.

Keywords: AlMgSi alloy, Natural aging, Microstructure, Mechanical properties, Sn

\section{Acknowledgement}

This work was supported by Scientific Grand Agency of Slovak Republic as a grant project VEGA No. 1/0812/16.

\section{References}

[1] POLMEAR, I. (2006). Light Alloys, From Traditional Alloys to Nanocrystals. Elsevier, Butterworth-Heinemann, Oxford, Burlington

[2] LUŠTINEC, J., OČENÁŠEK, V., JELÍNEK, M. (2016). Structure of Al-Mg-Si cast and extruded rods for die forgings, In: Manufacturing Technology, Vol. 16, No. 5, pp. 1009-1013. Institute of Technology and Production Management University of J.E. Purkyne. Czech Republic.

[3] SINCAR, S. (2002). Free machining aluminum alloy containing bismuth or bismuth-tin for free machining and a method of use. US patent no. 6409966. Reynolds Metals Company, Richmond, VA, USA.

[4] FALTUS, J., PLAČEK, K. (1999). Slitina hliníku s dobrou obrobitelností. Patent CZ 286150 B6. Alusuisse Technology \& Management AG, Neuhausen am Rheinfall. Switzerland.

[5] BARTGES, C.W., KLEMP, T.J. (2004). Lead-free 6XXX aluminium alloy. European patent no. 1464717. Alcoa Center. PA, USA.

[6] TIMELLI, G., BONOLLO, B. (2011). Influence of tin and bismuth on machinability of lead free 6000 series aluminium alloys. In: Materials Science and Technology, Vol. 27, No. 1, pp. 291-299. Taylor \& Francis Group. UK.

[7] FALTUS, J., BENDÍKOVÁ, E., UHLÍŘ, J. (2007). Influence of chemical composition on structure and properties of lead-free machinable AA 6023 (Al-Mg-Si-Sn-Bi) alloy. In: Acta Metallurgica Slovaca, Vol. 13, SI 1, pp. 597603. HF TU v Košiciach. Slovakia.

[8] ANDERSEN, S., ZANDBERGEN, H., JANSEN, J., TRÆHOLT, C., TUNDAL, U., REISO, O. (1998). The crystal structure of the $\beta^{\prime \prime}$ phase in Al-Mg-Si alloys. In: Acta Materialia, Vol. 46, No. 9, pp. 3283 - 3298. Elsevier BV. Netherlands.

[9] MATSUdA, K., SAKAGUCHI, Y., MiYATA, Y., UETANI, Y., SATO, T., KAMIO, A., IKENO, S. (2000). Precipitation sequence of various kinds of metastable phases in Al-1.0mass\% Mg2Si-0.4mass\% Si alloy. In: Journal of Materials Science, Vol. 35, No. 1, pp. 179-189. Springer US. USA.

[10] MARIOARA, C.D., ANDERSEN, S.J., ZANDBERGER, H.W., HOLMESTAD, R. (2005). The influence of alloy composition on precipitates of the Al-Mg-Si system. In: Metallurgical and Materials Transactions A, Vol. 36, No. 3, pp. 691-702. Springer US. USA.

[11] NINIVE, P.H., STRANDliE, A., GULBRANDSEN-DAHL, S., LEFEBVRE, W., MARIOARA, C.D., ANDERSEN, S.J., FRIIS, J., HOLMESTAD, R., LØVVIK, O.M. (2014). Detailed atomistic insight into the $\beta^{\prime \prime}$ phase in Al-Mg-Si alloys. In: Acta Materialia, Vol. 69, pp. 126-134. Elsevier BV. Netherlands. 
[12] MORAVEC, J., NOVÁKOVÁ, I., BRADÁČ, J. (2016). Effect of age hardening conditions on mechanical properties of AW 6082 alloy welds, In: Manufacturing Technology, Vol. 16, No. 1, pp. 192-198. Institute of Technology and Production Management University of J.E. Purkyne. Czech Republic.

[13] KOVALČÍK, T., STOULIL, J., SLÁMA, P., VOJTĚCH, D. (2015). The influence of heat treatment on mechanical and corrosion properties of wrought aluminium alloys 2024 and 6064, In: Manufacturing Technology, Vol. 15, No. 2, pp. 148-155. Institute of Technology and Production Management University of J.E. Purkyne. Czech Republic.

[14] RØYSET, J., STENE, T., SÆTER, J.A., REISO, O. (2006).The Effect of Intermediate Storage Temperature and Time on the Age Hardening Response of Al-Mg-Si Alloys. In: Materials Science Forum, Vols 519-521, pp 239244. Trans Tech Publications. Switzerland.

[15] POGATSCHER, S., ANTREKOWITSCH, H., WERINOS, M., MOSZNER, F., GERSTL, S.S.A., FRANCIS, M.F., CURTIN, W.A., LÖFFLER, J.F., UGGOWITZER, P.J. (2014). Diffusion on demand to control precipitation aging: application to Al-Mg-Si alloys. In: Physical Review Letters, Vol. 112, No. 22, pp. 225701-1 - 2257015. American Physical Society. USA.

[16] WERINOS, M., ANTREKOWITSCH, H., EBNER, T., PRILlHOFER, R., CURTIN, W.A., UGGOWITZER, P.J., POGATSCHER, S. (2016). Design strategy for controlled natural aging in Al-Mg-Si alloys. In: Acta Materialia, Vol. 118, pp. 296-305. Elsevier BV. Netherlands.

[17] SHISHIDO, H., TAKAKI, Y., KOZUKA, M., MATSUMOTO, K., ARUGA, Y. (2017). Effects of Sn Addition on Clustering and Age-Hardening Behavior in a Pre-aged Al-Mg-Si Alloy. In: Materials Science Forum, Vol. 877, pp. 455-460. Trans Tech Publications. Switzerland.

[18] STULÍKOVÁ, I., FALTUS, J., SMOLA, B. (2007). Influence of composition on natural ageing of Al-Mg-Si alloys. In: Kovové Materiály, Vol. 45, No. 2, pp. 85-90. SAV. Slovakia.

[19] FUJDA, M., MATVIJA, M., ZUBKO, P. (2014). Comparison of the Natural Ageing Behaviour of EN AW 6082 and Lead Free EN AW 6023 Aluminium Alloys. In: Key Engineering Materials, Vol. 586, pp. 125-128. Trans Tech Publications. Switzerland.

[20] BIROL, Y. (2006). The effect of processing and Mn content on the T5 and T6 properties of AA6082 profiles. In: Journal of Materials Processing Technology, Vol. 173, No. 1, pp. 84-91. Elsevier BV. Netherlands.

[21] BANHART, J., CHANG, C.S.T., LIANG, Z., WANDERKA, N., LAY, M.D.H., HILL, A.J. (2010). Natural Aging in Al-Mg-Si Alloys - A Process of Unexpected Complexity. In: Advanced Engineering Materials, Vol. 12, No. 7 , pp. 559-571. WILEY-VCH Verlag GmbH \& Co. KGaA. Germany.

[22] ROBINSON, J.M. (1994). Serrated flow in aluminium base alloys. In: International Materials Reviews, Vol. 39 , No. 6, pp. 217-227. Taylor \& Francis Group. UK. 